\section{Reduce Air Infiltration in Furnaces}

Fuel-fired furnaces discharge combustion products through a stack or a chimney. Hot furnace gases are less dense and more buoyant than ambient air, so they rise, creating a differential pressure between the top and the bottom of the furnace. This differential, known as thermal head, is the source of a natural draft or negative pressure in furnaces and boilers.

A well-designed furnace (or boiler) is built to avoid air leakage into the furnace or leakage of flue gases from the furnace to the ambient. However, with time, most furnaces develop cracks or openings around doors, joints, and hearth seals. These openings (leaks) usually appear small compared with the overall dimensions of the furnace, so they are often ignored. The negative pressure created by the natural draft (or use of an induced-draft fan) in a furnace draws cold air through the openings (leaks) and into the

\section{Suggested Actions}

Taking the following actions can reduce air leakage in a furnace:

1. Repair the air leakage area by replacing or repairing insulation or seals.

2. Close furnace doors properly to maintain a tight seal and avoid opening.

3. Install a pressure control system that maintains balanced, slightly positive (in hundredths of an inch) pressure, at the point of major air leakage.

4. Install a damper in the stack that can be adjusted manually if an automated furnace pressure control cannot be used or justified.

5. Install or use a "draft gage" to monitor furnace pressure at the level of air leakage if it cannot be sealed properly, and adjust the manual damper to maintain balanced, slightly positive (in hundredths of an inch) pressure, at the point of major air leakage.

Note: Actions 3-5 work only in forced and balanced draft furnaces.

\section{Resources}

See also Improving Process Heating System Performance: A Sourcebook for Industry. Washington, D.C.: U.S. Department of Energy and Industrial Heating Equipment Association, 2004.

U.S. Department of EnergyFor additional information on process heating system efficiency, to obtain DOE's publications and Process Heating Assessment and Survey Tool (PHAST) software, or to learn more about training, visit the BestPractices Web site at www. eere.energy.gov/industry/bestpractices.

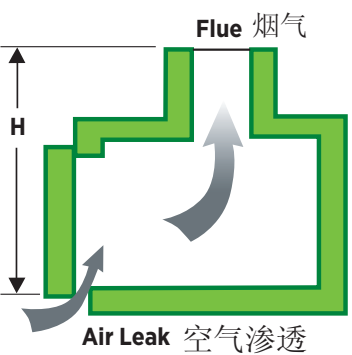

Figure 1. Air leakage and gas flow in a typical fuel-fired furnace. 图1. 典型的使用燃料的 熔炉中的空气渗透和流向

furnace. The cold air becomes heated to the furnace exhaust gas temperature and then exits through the flue system, wasting valuable fuel. It might also cause excessive oxidation of metals or other materials in the furnaces.

The heat loss due to cold air leakage resulting from the natural draft can be estimated if you know four major parameters:

- The furnace or flue gas temperature

- The vertical distance $\mathrm{H}$ between the opening (leak) and the point where the exhaust gases leave the furnace and its flue system (if the leak is along a vertical surface, $\mathrm{H}$ will be an average value)

- The area of the leak, in square inches

- The amount of operating time the furnace spends at negative pressure.

Secondary parameters that affect the amount of air leakage include these:

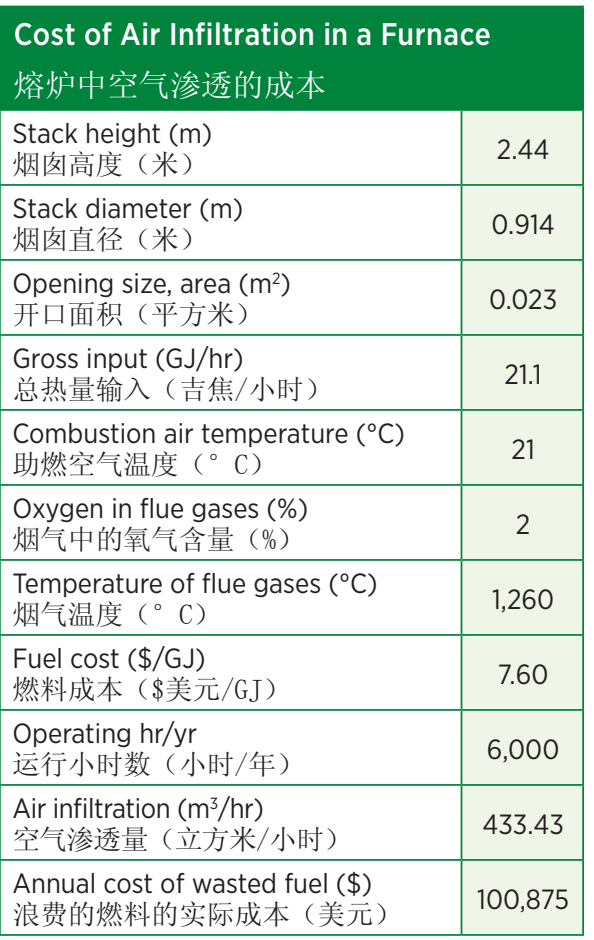

- The furnace firing rate

- The flue gas velocity through the stack or the stack cross-section area

- The burner operating conditions (e.g., excess air, combustion air temperature, and so on).

For furnaces or boilers using an induceddraft (ID) fan, the furnace negative pressure depends on the fan performance and frictional losses between the fan inlet and the point of air leakage. In most cases, it would be necessary to measure or estimate negative pressure at the opening.

The amount of air leakage, the heat lost in flue gases, and their effects on increased furnace or boiler fuel consumption can be calculated by using the equations and graphs given in Industrial Furnaces (see W. Trinks et al., below). Note that the actual heat input required to compensate for the heat loss in flue gases due to air leakage would be greater than the heat contained in the air leakage because of the effect of available heat in the furnace. For a high-temperature furnace that is not maintained properly, the fuel consumption increase due to air leakage can be as high as $10 \%$ of the fuel input.

\section{Example}

An industrial forging furnace with an 2.44 meter (m) stack operates at $1,260^{\circ} \mathrm{C}$ for 6,000 hours per year ( $\mathrm{hr} / \mathrm{yr}$ ) on natural gas costing $\$ 7.60 /$ GJ. The door of the furnace has an unnecessary 0.023 square meter $\left(\mathrm{m}^{2}\right)$ opening at the bottom that allows air to infiltrate. The table below shows the annual cost of the fuel that would be wasted because of the leak.

\section{Furnace Pressure Controllers}

Furnace pressures fluctuate with the burner firing rate and tend to be lowest at the lowest firing rates. To compensate for this constantly changing condition, a furnace pressure control system is used. It consists of a stack damper automatically controlled to maintain a neutral or slightly positive pressure in the combustion chamber. As burner firing rates decrease, the damper throttles the flow out of the stack to hold the pressure constant. Many different types of pressure controllers are available for use with furnaces and boilers. See the tip sheet titled Furnace Pressure Controllers for more information.

\section{References 参考文献}

Fan Engineering. Robert Jorgensen, ed. New York: Buffalo Forge Company. 1961.

Gas Engineers Handbook. George C. Segeler, ed. New York: The Industrial Press. 1968.

W. Trinks et al. Industrial Furnaces, Sixth Edition. New York: John Wiley \& Sons, Inc. 2003. 
减少渗透进入熔炉的空 气量

使用燃料的熔炉通过烟图向外排放燃烧产 物。排出的熔炉烟气密度比空气低, 也比 空气更轻, 因此烟气上升, 在熔炉的顶部 与底部之间产生压差。这个压差, 也称为 热位差, 是熔炉或锅炉中产生自然通风或 负压的原因。

设计良好的熔炉（或锅炉）建好后可以避 免空气渗透进入熔炉, 或避免烟气从熔炉 泄漏到周围空气中。然而, 随着时间的推 移, 绝大多数熔炉会在炉门、连接处、和 炉台密封处产生裂缝或开口。这些开口（ 或裂缝）的大小通常比熔炉整体的尺寸小 很多, 因此经常容易被忽略。熔炉中的负 压, 由自然通风（或利用排气式引风机） 造成, 将冷空气从这些开口 (或裂缝) 中 吸入炉内。冷空气在炉内被加热到烟气的 温度, 然后通过烟气系统排掉, 浪费了宝 贵的燃料。同时，也可能造成炉内金属或 其它材料的过度氧化。

由自然通风导致的冷空气渗透, 从而产生 的热损失, 您可以利用以下四种主要的参 数对热损失量进行估算。

- 熔炉或烟气的温度

- 开口 (裂缝) 的位置与熔炉或烟气系 统排放烟气的位置之间的垂直距离 （H）（如果裂缝是在垂直表面上, 则 计算垂直距离的平均值)

- 裂缝面积, 以平方米为单位

- 熔炉在负压状态下的运行时间

会影响空气渗透量的二级参数包括以下这 些:

- 熔炉的燃烧率

- 烟气经过烟图或烟图横截面积的速度

- 燃烧器的运行条件 (如, 过量空气、 助燃空气温度等)

采用排气式引风机的熔炉或锅炉, 熔炉的 负压取决于风机的性能, 以及风机进气口 和空气泄漏处之间的摩擦损失。在绝大多 数情况下, 有必要测量或估算开口处的负 压。
建议采取的节能行动

当评估余热是否能用于加热次要工艺时, 请 考虑以下问题:

1. 是否还有更便宜的方法来加热次要工 艺?

2. 用于加热次要工艺的烟气温度是否足够 高?

3. 烟气中是否含有足够的可转移的能源?

4. 烟气是否与次要工艺的要求相符合 (如 烟气的清洁度和腐蚀程度等）？

5. 主要工艺可以及时将能源送至次要工艺 吗?

6. 主要工艺与次要工艺的位置是否足够 近, 从而避免在余热传输中额外的热损 失?

7. 次要工艺排出的烟气的温度是否足够 高, 从而避免水分凝结带来的问题?

8. 是否可以将废气管道和次要工艺设计得 避免对烟气出现过多的压力阻力? 或 者, 是否需要额外手段（如排风机）?

\section{资源}

参见ASM Handbook, Volumes 1 (1990) and 2 (1991), Materials Park, OH: ASM International; Combustion Technology Manual, Fifth Edition, Cincinnati, $\mathrm{OH}$ : Industrial Heating Equipment Association (IHEA), 1994; Handbook of Applied Thermal Design, E.C. Guyer and D.L. Brownell, eds., London: Taylor \& Francis Group, 1999.

美国能源部一一如需进一步了解过程加热系 统能效的信息, 获取美国能源部的报告以及 过程加热评估工具 (PHAST工具), 或想进 一步了解有关培训, 请访问美国能源部工业 技术项目 “最佳实践” 的网站Www.eere. energy.gov/industry/bestpractices。

空气渗透量, 烟气中的热损失量, 以及它 们对增加熔炉或锅炉燃料消耗的作用, 可 以通过《工业熔炉 (Industrial Furnaces) 》中所给出的公式和图表进行计算 (见参 考文献中W. Trinks 等人所著一书)。请注 意, 由于有效热量的作用, 为补偿由空气 渗透所造成的烟气热损失而提供的实际热 量, 比热损失带走的热量要高。对于高温 熔炉而言, 如果没有进行很好的维护, 空 气渗透所造成的热损失, 可高达燃料输入 的 $10 \%$, 也就是将燃料消耗提高了 $10 \%$ 。

\section{示例}

一台工业锻造炉，它的烟图高2.44米（8英 尺），每年在温度为 $1260^{\circ} \mathrm{C}$ 的状态下运 行 6000 小时。采用天然气为燃料, 价格为
$\$ 7.6$ 美元/吉焦 (GJ)。炉门底部有一个大 小为 0.023 平方米 (36平方英寸) 的不必要 的开口, 让空气得以渗透进熔炉中。下表 显示了由于空气渗透造成的每年燃料成本 的浪费。

\section{熔炉压力控制器}

熔炉压力会随着燃料的燃烧率而起伏变 化, 在燃烧率最低时, 熔炉压力通常最 低。为了管理这一不断变化的情况, 可采 用熔炉压力控制系统。该系统装有烟图闸 板, 可以通过对它的自动控制, 将燃烧炉 内的压力维持在零压或轻度的正压状态 下。随着燃料燃烧率的下降, 闸板可减少 烟气的排放，从而维持压力。可从市场上 获得许多不同种类的压力控制器, 供熔炉 和锅炉使用。请参见在题为 “熔炉压力控

\begin{abstract}
BestPractices is part of the Industrial Technologies Program Industries of the Future strategy, which helps the country's most energy-intensive industries improve their competitiveness. BestPractices brings together emerging technologies and best energy-management practices to help companies begin improving energy efficiency, environmental performance, and productivity right now.

BestPractices emphasizes plant systems, where significant efficiency improvements and savings can be achieved. Industry gains easy access to near-term and long-term solutions for improving the performance of motor, steam, compressed air, and process heating systems. In addition, the Industrial Assessment Centers provide comprehensive industrial energy evaluations to small- and medium-size manufacturers.
\end{abstract}

“最佳实践（BestPractices）” 是工 业技术项目 “未来产业” 战略的一部 分, 它可帮助高能耗的产业提高竞争 力。“最佳实践 (BestPractices)” 提供新兴技术以及最佳能源管理实践 方面的信息, 帮助公司改善能源效 率，提高环保绩效，并提升生产效 率。

“最佳实践（BestPractices）”强调 工厂系统的重要性, 从工厂系统的角 度实现能效的大幅提高, 并获得显著 的节能量。企业可获得提高风机、蒸 汽系统、空气压缩系统和过程加热系 统绩效的近期和长期的解决方案。此 外, 工业评估中心向中小型企业提供 全面的工业能源评价。

\section{Es:Terey}

Energy Efficiency \&

Renewable Energy
EERE Information Center

DOE/GO-102011-3432 • October 2011

能效和可再生能源信息中心

1-877-EERE-INFO (1-877-337-3463)

www.eere.energy.gov/informationcenter

Printed with a renewable-source ink on paper containing at least $50 \%$ wastepaper, including $10 \%$ post consumer waste.

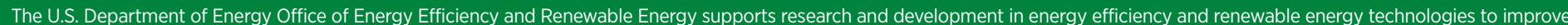

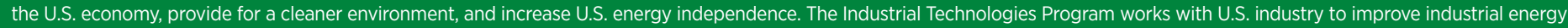
efficiency and environmental performance.

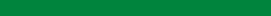

